Gas" (Soc. Chem. Indust. Journ., I885); “ On some Sulphur Compounds of Barium" (Chem. Soc. Journ, 1886); "On the Conditions of Evolution of Gases from Homogeneous Liquids" (Phil. Trans., 1888); "On a Method of Investigating the Dissolution of Metals in Acids" (Chem. Soc. Journ., 1889); “On the Conditions of the Reaction between Copper and Nitric Acid" (Roy. Soc. Proc., 1889).

THE ARCTIC EXPEDITIONS OF IS97.

$\mathrm{T}$ is not easy to speak definitely regarding the various Arctic Expeditions which will be in the field this year, for several of the most loudly advertised ventures have collapsed or been postponed, and it is possible that some quiet and determined explorers may set out without calling public attention to their plans. There is un. doubtedly to be keen rivalry in the North Polar basin for several years to come, and even an incomplete fore. cast of the projected work may serve to direct notice to the regions whence good results in the way of Arctic discovery may be looked for. It is unnecessary to insist. in the pages of NATURE, however needful the caution may be to the general public, that no credit for Arctic exploration can be given until the intending explorer returns, bringing with him proofs of his achievements which will bear the keenest criticism of experts.

Two well equipped expeditions have been in the field since last summer, working by different methods, from different sides, but both led by men of experience and manned by tested Arctic travellers. Nansen's expedition in the Fran appeals most powerfully to the imagination for the boldness of its plan and the faith with which its leader bases his success and even his life on the truth of his theory of ocean-currents in the far north. The general trend of these currents, as drawn by Dr. Nansen, is shown on the accompanying map, which is reduced from one published in the Geographical Journal, vol. ii. His strongest evidence for the existence of a drift across the centre of the polar basin was, as is well known, the discovery on the ice off the south of Greenland of relics from the American exploring ship Jeannette, which sank off the New Siberian Islands; but this was fortified by much additional information. The Fram sailed from Christiania on June 24, 1893, passed through the IVaigatz Strait on August 3, and the last news was that on August 6 some Samoyeds saw her passing along the Yalmal coast between the ice and the land. Nansen intended to call at the mouth of the Olenek River in September before turning finally northward, but he did not do so. If he had called, or even been sighted off the coast, the fact would have been reported to Baron Toll, who was in the neighbourhood of the Olenek until November. It seems probable that, making an easy passage across the Kara Sea, Dr. Nansen found sufficiently open water to induce him to turn northward off Cape Chelyuskin, as he was urged to do by Captain Wiggins, and that the Fram has passed the winter fast in the ice somewhere within the Soth parallel, possibly drifting polewards. No news can now be looked for by way of Siberia, and it is very unlikely, though just possible, that one of the expeditions going north this year, by Franz-Josef Land or Spitzbergen, may meet the crew of the Fram, where all meridians converge towards the pole.

Mr. Peary, after raising the necessary funds in America by writing and lecturing, returned to the scene of his former triumphs at Independence Bay on the north-east coast of Greenland. $\mathrm{He}$ and his party landed at Bowdoin Bay on Inglefield Gulf in Smith Sound on August 3, I 893 , and established themselves there for the winter, being comfortably settled when the steamer left on August 20. Sledging parties were at once despatched to cache provisions at convenient depôts on the inland ice on the way to Independence Bay. Mr. Peary intended to commence his main journey about the middle of
March this year, and to reach Independence Bay in the first week of May. Here the party will divide, three men being despatched to sledge south-eastward and survey the coast along the quite unknown stretch to Cape Bismarck, returning thence across the ice-cap to Inglefield Gulf. The other party will push northward from Independence Bay, and endeavour to completely survey the land which was seen across the strait last year, at the same time trying to attain the farthest north. The position of Navy Cliff, on the south side of Independence Bay, was fixed as $81^{\prime \prime} 37^{\prime}$, and since Lockwood's farthest north was $83^{\circ} 24^{\prime}$, it is practically certain that Peary, with his great experience of foot-travel on the ice, will be able to make his way more than the 125 miles which would carry him nearer the pole than any previous traveller. This year he is not to depend entirely on dogsledges, but to experiment with Mexican donkeys, which are accustomed to carry heavy loads in the low temperature and thick snow of the high Cordilleras. Whatever the result may be in record-breaking of northern latitudes, we may confidently expect a great deal of solid geographical and scientific work from this expedition. A steamer will call at Bowdoin Bay to bring back the party, or at least obtain news of them, in August or September.

The third expedition left Tromsoe on May I, I894 for Spitzbergen, with the object of repeating the attempt so gallantly made by Parry in 1827 , when he reached $82^{\circ} 45^{\prime}$. It is under the command of Mr. Walter Wellman, a journalist of Washington, who has carefully thought nut his plan of action, and has commenced to carry it into effect without delay. Although he has had no previous Arctic experience, he is a man of great energy and enthusiasm; his companions are as enthusiastic and resolute as himself, and it is by no means improbable that he may be able to give a good account of his time. He terms his enterprise "a dash for the pole," and is determined to be back in America before the end of October. However, as a precautionary measure he is to provision the old seal-hunters' house on Danes Island in the north-west of Spitzbergen for a year, in case of enforced wintering. The object of starting so early in the season is to avoid the strong southerly drift of the ice, which so greatly hampered Parry's sledging parties. Thus, if Mr. IVellman's theory is correct, he will reach his farthest north before the drift becomes serious, and have the southward drifting ice-floes to help him on his return. By the use of very light boats, constructed entirely of aluminium, and provided with runners to convert them into sledges, the weight to be pulled will be greatly reduced. It is to be feared that Mr. Wellman's plan of taking Belgian draught dogs for his sledges will lead to difficulties on account of the difference in climate and in the nature of the work from those to which they are accustomed. The behaviour of the aluminium boats will be looked forward to with much interest.

Finally, the Jackson-Harmsworth expedition will take the field early in July, having for its purpose the exploration of the polar area lying north from Franz-Josef Land. Mr. Harmsworth, who is bearing the whole cost of the expedition, has purchased the Windward, of Peterhead, a well-known steam whaler of 320 tons, to take the party out to Franz-Josef Land, but the exploration will be conducted by land or across the ice. Mr. F. G. Jackson, the originator and leader of the expedition, has long thought over this matter, and devoted most of his time for two years to the study of Arctic problems. He spent a great part of last winter in the nnrth of Russia,testing sledges and other appliances for ice-travel and practising surveying on the little-known IVaigatz Island. Like Peary, he intends to try the endurance of stronger animals than dogs in Arctic work, proposing to take a number of Russian ponies. The personnel of the expe-

NO. 1281 , VOL. 50] 
dition, although probably not exceeding six, will include trained specialists and collectors, who will map their route, make meteorological and masnetic observations, and collect geological, botanical, and zoological specimens. After calling at Archangel, in the end of July, to take on board a Russian log-house, and then at Khabarova to ship Vest Siberian dogs and drivers, the Wintzuard will proceed to Franz.Josef Land and make a landing. somewhere in the south of that region, the exact spot depending on the state of the ice. The route to and his companions : will spend the winter at their base, where the conditions of life were found to be quite endurable by Mr. Leigh Smith when he was compelled to spend a winter there, with very poor accommodation and equipment, after the wreck of his yacht, the Eirat, in 1881. Early in the spring of 1895 the expedition would push northivard, moving very slowly because of the necessity of traversing the distance several times over in order to carry the quantity of stores necessary to establish a depôt every thirty or forty miles along the

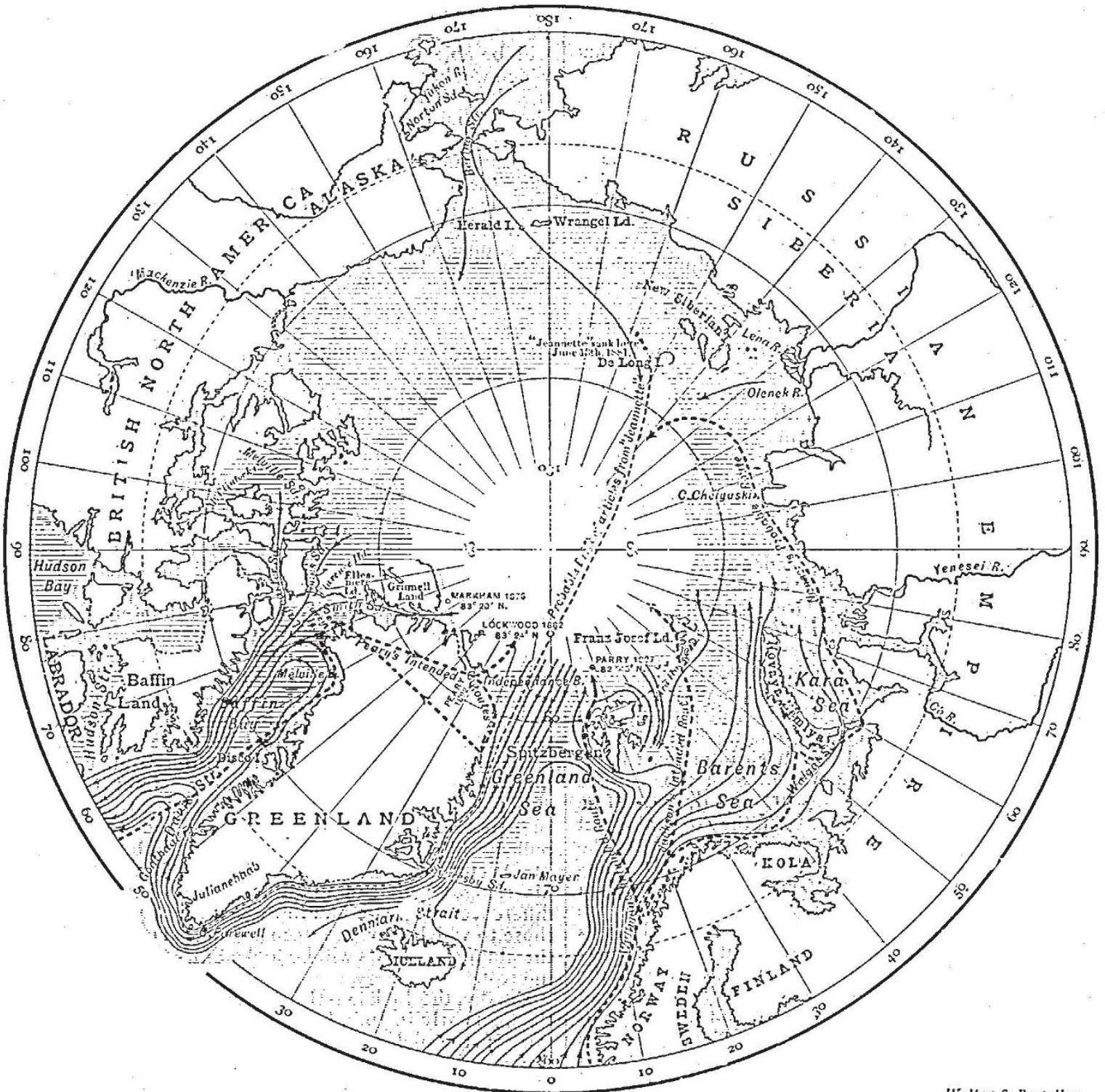

North Polar Map to illustrate projected Polar Exreditions.

Hatker E- Bizuall se.

Franz-Josef Land will thus be due north from near Kolgueff Island, instead of north-eastward from Norway as shown on the map. The wooden house vill be erected on a secure and sheltered site, and stocked with the necessary stores for four years, after which the ship will return. If, as seems possible from Payer's observations, Austria Sound should be found open, provisions will be carried north along it in a steamlaunch and cacheil for subsequent use. Mr. Jackson route. This slow progress will, of course, give an opportunily for repeating observations for position, and so add to the accuracy of the map. The direction of advance will probably be along Austria Sound and across Petermann Land, the farthest north sighted by Payer in the Austro-Hungarian expedition, and lying in $\delta 3^{\circ} \mathrm{N}$. Should Petermann Land extend to the north, Mr. Jackson intends to proceed along it, mapping his route as he goes. Boats would be carried for crossing

No. I $2 \delta I$, vOI. 5O] 
open water, and if ocearic ice intervenes, it would be traversed as rapidly as possible, and a return made to the farthest north point on solid land, where winter-quarters could be established; but should this be impracticable, the retreat would be continued to the base, where the second winter would be spent. In the spring of 1896 the party would turn northward again, the chain of depôts accelerating their progress. In the summer of $1 \& y 6$ the ship will return with additional stores and men, and to obtain news ; but it does not appear to be Mr. Jackson's intention to return, unless he is satisfied that his work is final, until 1897 . This expedition ought certainly to extend our knowledge of the most northerly land known, and if fortune favours it, the advances made may be great. Its equipment is of the very best, and no excuse of bad material can be brought forward to explain unsatisfactory results.

The expedition for the exploration of Ellesmereland, to which reference has several times been made in NATURE, planned by Mr. Robert Stein, of the U.S. Geological Survey, has been postponed; we hope only until next season. Still efforts will be made this summer to clear up the fate of the unfortunate young Sivedish naturalists, Björling and Kalstennius, with their mate, Gilbert Dunn, and cook, Herbert MacDonald, of whom the last news received was that they intended to seek shelter with the reported Eskimo of Ellesmere Land. Mr. Elis Nilson has been sent out by the Swedish Anthropological and Geographical Societies, on the Dundee whaler Eclipse, to visit the Carey Islands and Clarence Head, if the ice permits, and search for any relics of the missing party, whose fate, after two years without supplies, can scarcely be considered doubtful. Baron Norden. skjöld has interested himself particularly in the search, and will probably arrange for other whalers to deviate from their course in order to obtain information.

Dr. F. A. Cook, the ethnologist on Peary's former expedition, has issued a prospectus of a pleasure trip which he is to conduct up Baffin's Bay to Smith Sound, with the opportunity of a slight change of route should any of the passengers desire it. This would, if the state of the ice yermitted, render it possible to call at Clarence Head and the Carey Islands, and make at least a hasty search for the missing party ; but a pleasure trip scarcely lends itself to serious Arctic exploration.

Prophecy with regard to the results of geographical exploration is too uncertain to be indulged in by modern critics, and in Arcticexploration particularly the conditions are so difficult to predict that success may attend the most inexperienced and worst equipped, while experience and all the resources of wealth and science would struggle in vain against adverse conditions. There are certain remarkable features about the new expeditions which distinguish them from most of the earlier efforts. Each has been planned and is being carried out by a man who is thoroughly in earnest, and whose reputation rests on his success. This is widely different from the case of a commander "ordered" to carry out the plans of others. Each expedition is small; Nansen's, which is the largest, comprises only thirteen men. Two of those which have already faced the awful monotony of the Arctic night, have appliances for dissipating the darkness by the electric light, an advantage which can hardly be over-estimated in its effect on the spirits of the men. Provisions and equipments have been greatly im. proved, even since the time of the Alert and Discovery and of the Feannette. Most important of all, three of the expeditions are free from the responsibility of a ship. In all these ways the four serious attempts of this year have elements of success never combined previously. Their results will not be known for some time. News of Mr. Peary will certainly be received this autumn by the vessel to be sent up to Inglefield Gulf to bring him home if he considers his work satisfactorily finished. It is probable that MIr. IVellman also will return; but unless he should by some scarcely credible good fortune meet the crew of the Fram at his farthest north, we cannot hope to hear of Nansen for another year at least; and Mr. Jackson's scheme provides for a possible absence on his part for four years, though progress should be reported before the end of next year.

HUGH Robert MILL.

\section{THE CRINOIDEA OF GOTLAND.}

THIS is the first instalment of a memoir based on a revision of the specimens of crinoids in the Angelin collection at Stockholm. It is published in English, and is illustrated by Mr. G. Liljevall, who has produced 382 : remarkably beautiful figures upon ten quarto plates. Their accuracy may be relied on by those who know Mr. Bather's own scrupulous carefulness as an artist.

The author commences by pointing out the need for a thorough re-examination of the Stockholm specimens, the drawings in Angelin's "Iconographia Crinoideorum" being so frequently misleading, and having been in many cases produced by a union of several distinct individuals. The older palaentologists certainly had not that reverence for type-specimens which now very justly prevails among curators; they brought out, as they thought, the salient points of their specimens, filled in a sort of fancy groundwork of rock around the drawing, and left students to search in vain in the collection for the exact object that had thus been honoured above the others.

The classification of the Crinoidea undergoes considerable changes with each new descriptive paper, and Mr. Bather's works are a healthy example of receptivity and indifference to precedent. IVe read each in the light of the glossary appended to it, ridding our minds as far as possible of the technicalities that we have previously learned. We must confess that such changes in nomenclature are based on observation and on additions to our knowledge, and we need only quarrel with the terminology when it is reduced to algebraic symbols.

The abolition of the Fistulata and the Larviformia as sub-orders of the Inadunata (p. 8), and the substitutionquite temporarily - of divisions based on the presence or absence of infrabasals, may be hailed as a simplification, allowing more latitude in the association of the scveral genera. But the value of such close and detailed work. as that of the present memoir will depend in no way upon the stability of the classification utilised. Mr. Bather (p. I9) can thus treat even the Inadunata as a convenient portmanteau, soon to be worn out; and specialists will turn with pleasure to the critical descriptions of individual specimens in the collections.

A fine example of how the collation of specimens, year after year, will add profoundly to our knowledge of ancient life upon the earth, is to be found in the story of Herpetocrimus (pp. 36-45). The crown of this genus was detected in certain Dudley specimens by Mr. Bather himself, Salter's opinion being thus amply verified; and the coiled stem, often supposed to be an arm, is now shown to have had a permanent tendency (p. 45), by its very structure, to bend round in one direction, while it could probably be uncoiled "by the simple contraction of the large musc'es on the outer part of the articular surface." With a quaintness of expression now familiar to us, our author proceeds: "It is very probable that the animals usually broke off any rooted attachment they may have formed, and that they clung to corals or other submarine objects by their cirri." It is further suggested that they could move from one spot to another.

x "The Crinoidea of Gotland." Part i. The Crinoidea Inadunata. By F. A. Bather, M.A., F.G.S. (Stockholm: Kongl. Svenska Vet.-Akad, Handl. Bt. 25. 1893 .)

$$
\text { NU. I } 28 \text { I, vOL. 50] }
$$

